\title{
Comparison between IMTA and monoculture farming of mussels (Mytilus galloprovincialis L.) in the Boka Kotorska Bay
}

\author{
Slađana GVOZDENOVIĆ ${ }^{1}$, Milica MANDIĆ ${ }^{2}$, Vladimir PEŠIĆ ${ }^{3}$, Marko NIKOLIĆ ${ }^{1}$ \\ Ana PEŠIĆ ${ }^{2}$ and Zdravko IKICA²*
}

\author{
${ }^{1}$ BIO-ICT Centre of Excellence in Bioinformatics, Cetinjska br. 2, 81000 Podgorica, Montenegro \\ ${ }^{2}$ Institute of Marine Biology, University of Montenegro, Dobrota b.b., 85330 Kotor, Montenegro \\ ${ }^{3}$ Faculty of natural sciences and mathematics, University of Montenegro, Cetinjska br. 2, 81000 \\ Podgorica, Montenegro
}

*Corresponding author, e-mail: zdikica@ac.me

This paper presents the resuls of growth rate and condition index analysis of Mytilus galloprovincialis in integrated system and monoculture. The aim of this study was to show if there are differences in growth and condition index of mussels between integrated multi-trophic aquaculture (IMTA) and monoculture farming. The growth rate and condition index were monitored during a 13-month study at three different sites: 1) close to fish cages (NBL), 2) $100 \mathrm{~m}$ removed from fish cages (NUD), 3) at a monoculture mussel farm (SVN) around $8 \mathrm{~km}$ far away from cages. The most intense growth of mussels was recorded in spring, and the least intense in summer. After 13 months, monitored individuals at all three locations achieved commercial size. The growth rate was very similar at all sites. The condition index showed spatial and temporal differences. Condition index values on site NUD were mostly higher compared to SVN and NBL, which were very similar, exept for the period from October to December when CI was similar on NBL and NUD site and higher in comparation with SVN. CI values on NBL an NUD site during cold period indicate on fact that mussels probably feed on the nutrients from fish farm origins. The highest mortality rate was recorded at the NBL site, probably due to the effects of fouling organisms.

Key words: Mytilus galloprovincialis, integrated multi-trophic aquaculture (IMTA), monoculture, Boka Kotorska Bay

\section{INTRODUCTION}

Marine aquaculture or mariculture is a very important fish, crustacean, mollusc and algae production sector, which has the possibility to replace the reduced potential of natural resources (FAO, 2010). Nowadays, terms such as "integrated" and "multi-trophic" are increasingly used in relation to the concept of mariculture and aquaculture in general (CHOPIN \& ROBINSON, 2004). Integrated multi-trophic aquaculture
(IMTA) can be defined as the form of aquaculture where unconsumed fish food and fish metabolic products, which otherwise would have negative impact on the environment, can be used as a food source in another subsystem, leading to the increased productivity of the entire system under the complete control of the farmers (FAO, 2009; TROELL et al., 2009; CHÁVEZ-CROOKER \& OBREQUE-CONTRERAS, 2010). According to FAO (2004), one of the main goals of the aquaculture industry in the near future would be to minimize 
negative impacts on the environment in order to achieve long-term viability. IMTA can be a good mechanism for achieving this goal, while also achieving another benefit - the increased economical productivity of the entire system (SARÀ et al., 2009; RENDMOND et al., 2010; SARÀ et al. 2011; ŽUPAN 2012; MACDONALD et al., 2013; HOLDT \& EDWARDS, 2014; AL-HAFEDH et al., 2014; RATCLIFF et al., 2015).

Integrated multi-trophic farming systems of various marine organisms are known worldwide (FAO, 2009; ABREU et al., 2009; NAVARRETE-MIER et al., 2010; REID et al., 2010; HUGHES \& KELLY, 2011; HANDÅ et al., 2012; LANDER et al., 2012; IRISARRI et al., 2014a). The possibility of implementation of the integrated multi-trophic farming in the Mediterranean was well studied in the last ten years (PEHARDA et al., 2007; NAVARRETE-MIER et al., 2010; SARÀ et al., 2011; ŽUPAN, 2012; ŽUPAN et al., 2012; ŽUPAN et al., 2013; ŽUPAN et al., 2014; ISARRI et al., 2014a). Bivalves are known as filter feeders and they could potentially remove organic matter as well as uneaten fish food from water (RENDMOND et al., 2010). According to SARÀ et al. (2009) and MAZZOLA \& SARÀ (2001) this process can reduce negative impact on environment. Some studies have shown that the farming period for achieving market size in integrated farming of mussels (Mytilus galloprovincialis) and fish is similar to that in commercial monoculture (PEHARDA et al., 2007). On the other hand, SARÀ et al. (2011) demonstrated higher growth rate of mussels (M. galloprovincialis) and the European flat oyster (Ostrea edulis) found close to fish farms compared to those found at the open sea. Higher condition index values of Noah's Ark shell (Arca noae) near fish farm, and the nearly identical periods for achieving market size of mussels (M. galloprovincialis) in integrated farming and monoculture have been proven by ŽUPAN (2012).

Mediterranean mussel, M. galloprovincialis Lamarck 1819 , is a widely distributed species, autochthonous to the Mediterranean (GISD, 2016). The mussel lives in colonies in the tidal zone, fastened to the substrate by byssal threads. It feeds on phytoplankton, bacteria, zooplankton and detritus (DAVENPORT et al., 2000; PRATO et al., 2010). Genders are separated, and the spawning occurs mostly in spring and autumn. The mussels are considered to be of market size when they are at least $5 \mathrm{~cm}$ in length (OFFICIAL GAZETTE OF MONTENEGRO, 8/2011; 56/2009, 47/2015).

The mussel farming tradition in the Boka Kotorska Bay area started about thirty years ago, although the first experiments regarding mussel and oyster farming begun in the 1960's (STJEPČEVIĆ, 1968). Today, there are 20 mussel farms in the Bay, all using floating park systems (long-lines). Gilthead sea bream (Sparus aurata Linnaeus, 1758) and European sea bass (Dicentrarchus labrax Linnaeus 1758) farming in the area started in the late nineties, and currently there are two farms (Orahovac and Stoliv) using the floating cage system farming method. The integrated farming of mussels and fish is used on both farms. In 2014, the mariculture production amounted to $45 \mathrm{t}$ of sea bass, $38 \mathrm{t}$ of sea bream, and $178 \mathrm{t}$ of mussels (MONSTAT, 2015).

The main goal of this study was to obtain some data on IMTA farming, due to fact that this kind of farming has not been sufficiently studied in neither the Adriatic nor in the Mediterranean.

\section{MATERIAL AND METHODS}

\section{Study area}

The study was conducted on two locations in the Boka Kotorska Bay, Montenegro (South Adriatic) (Fig. 1). One location was the fish and mussel farm "COGImar" in the settlement of Orahovac, Kotor municipality, $42^{\circ} 29^{\prime}$ 07.79" $\mathrm{N}, 18^{\circ} 44^{\prime} 42.47^{\prime \prime}$ E. The second location was Sveta Neđelja mussel farm in the Kamenari settlement, municipality of Herceg Novi, $42^{\circ}$ $27^{\prime} 30.89^{\prime \prime} \mathrm{N}, 18^{\circ} 40^{\prime} 21.42^{\prime \prime} \mathrm{E}$. The straightline distance between the two study locations is $8 \mathrm{~km}$. The COGImar farm farms Gilthead sea bream, European sea bass, Mediterranean mussel and European flat oyster in polyculture. On the COGImar localition two sites were chosen for the experimental part of the study: the mussel long-line closest to the floating fish cages (NBL), which was $10 \mathrm{~m}$ removed from the cages, and the mussel long-line furthest from the fich cages (about $100 \mathrm{~m}$ removed) (NUD). Sveta 
Neđelja farm is a monoculture bivalve farm which produces Mediterranean mussel as well as the European flat oyster, and therefore only one site was selcted (SVN).

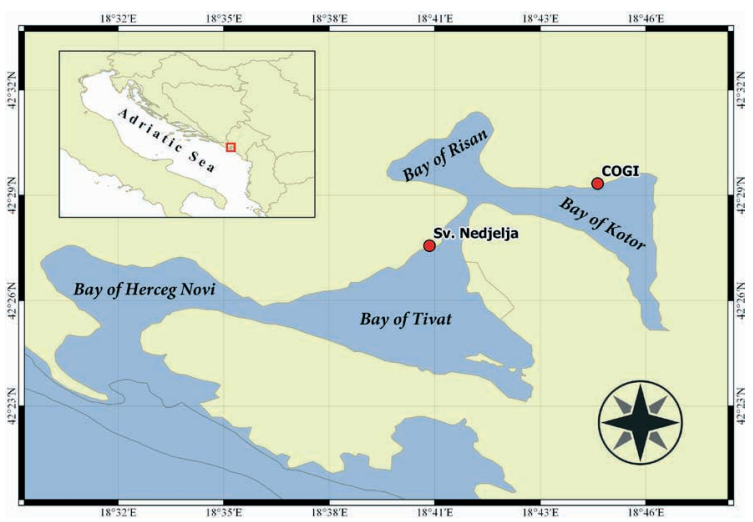

Fig. 1. Map showing the locations of sampling sites (NBL and NUD at COGI, SVN at Sv. Neđelja)

\section{Experimental design}

The growth experiment was set during a 13-month period, from January 2015 until January 2016. In January 2015, mussels of approximately the same size (mean length 4.27 $\pm 0.4 \mathrm{~cm}$ ) and age (around 8-10 months) were taken form the experimental farm at the Institute of Marine Biology, University of Montenegro, in Kotor. Mussels were cleaned of fouling organisms the same day, and shell lengths, widths and heights were measured using vernier caliper to the nearest $0.1 \mathrm{~mm}$. Individual mussels were marked using improvised tags. The tags were made from kitchen plastic waterproof mats (WelkHOME, Italy). The mats were cut to rectangles, approx. $12 \times 5 \mathrm{~mm}$ in size, and markings etched on the surface using scalpel and soldering iron, with the markings visibility improved using waterproof felt-tip marker. Numbered tags were bonded to mussel shells with two-component waterproof adhesive (ABRO EPOXY STEEL, U.S.A.). During the marking process, duration of air exposure was around 2-3 minutes, until the adhesive hardened. Marked and measured mussels were placed in plastic baskets $(48 \times 29 \times 5 \mathrm{~cm}$, with $2 \mathrm{~cm}$ stretched mesh size) and suspended in water at depths between 2 and $3 \mathrm{~m}$. At the COGImar location, 110 individuals were placed together on a farming line closest to the fish cages (NBL), and another 110 individuals on a farming line furthest from the fish cages (NUD). At the Sveta Neđelja location, 112 individuals were set together on a farming line (SVN). The mussels were checked every other month, removed from water, measured (length, width, height), cleaned from fouling organisms and resuspended in water.

Temperature and salinity on both localities were recorded monthly using the Multiline P4 WTW probe.

For condition index estimation, a total of 1,560 individual mussels of similar size and age (around 8-10 months) were taken from the experimental farm at the Institute of Marine Biology. Mussels were placed in nylon mesh nets (2-3 cm stretched mesh size). Fourty individual mussels were put in each net, with 13 nets per site (i.e. 39 nets in total). Nets were placed on NBL, NUD and SVN sites at depths between 2 and $3 \mathrm{~m}$. Once per month, one net from each site was taken. From each net 30 individual mussels were taken and processed in the laboratory the same day. The condition index was determined as the ratio between wet mass of meat (WMM) and total weight (TW), according to ALMEIDA et al. (1999).

\section{Statistical analyses}

Growth ratios were tested using repeatedmeasures two-way ANOVA with Tukey posthoc test. Parameters of von Bertalanffy's growth equation $\left.\left(\mathrm{L}_{\mathrm{t}}=\mathrm{L}_{\infty}\left[1-\mathrm{e}^{-\mathrm{k}(\mathrm{t}-\mathrm{t})}\right)\right]\right)$ were estimated with analysis of growth increment data using Munro's method in the FISAT II v.1.2.2 statistical package (GAYANILO et al., 2005).

The condition index samples were tested for normality of distribution of differences between each observation and the mean of its group using Kolmogorov-Smirnov test with Lilliefors significance correction.

The homogeneity of variance was tested using Fligner-Killeen test for samples that did not follow normal distribution, and with Bartlett test for those that did. Homoscedastic samples were then tested using one-way ANOVA, with 
Tukey HSD (Honestly Significant Difference) used as a post hoc test. Heteroscedastic samples were analysed using Kruskal-Wallis rank sum test, with Dunn's test as a post hoc test.

\section{RESULTS}

\section{Temperature and salinity}

Minimum and maximum temperatures at the COGImar location ranged between $11.6^{\circ} \mathrm{C}$ in February 2015 and $27.9^{\circ} \mathrm{C}$ in July 2015 . Temperature on the Sveta Neđelja location ranged between $10.5^{\circ} \mathrm{C}$ in January 2016 , and $26.5^{\circ} \mathrm{C}$ in August 2015 (Fig. 2A). Salinity on the COGImar location was between the minimal value of 13.8\% in February 2015, and the maximum value of $35.2 \%$ in December 2015. On the Sveta Neđelja location, the minimum salinity value of $19.8 \%$ was recorded in February 2015 , and the maximum values of $37.1 \%$ in December 2015 (Fig. 2B).
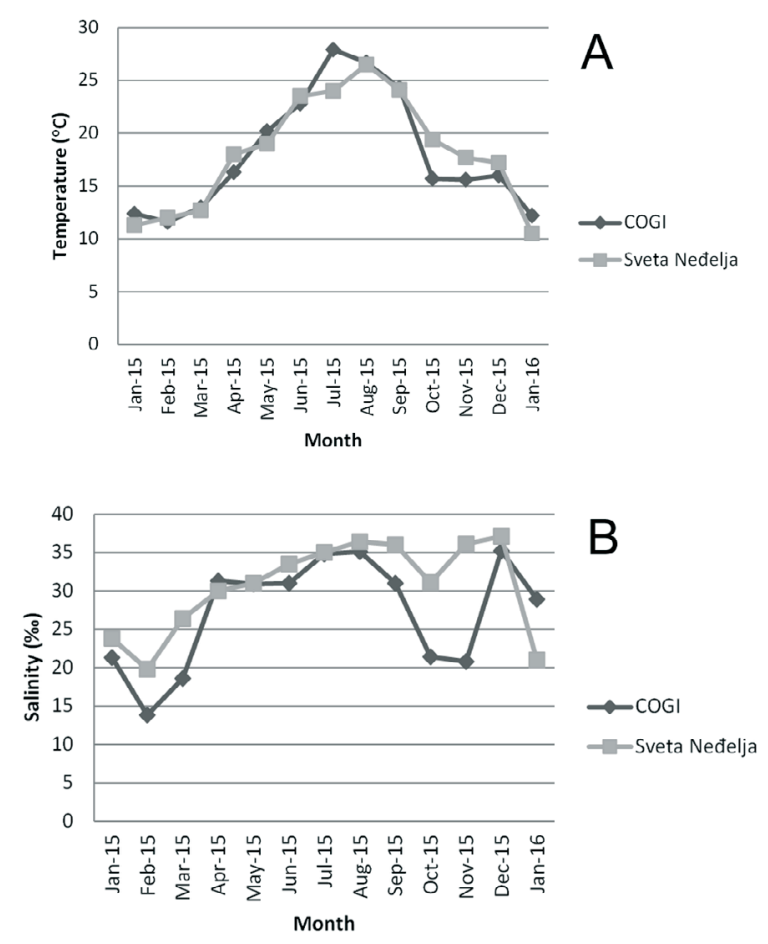

Fig. 2. Monthly temperature (A) and salinity (B) values on both localities (COGI and Sv. Neđelja)

\section{Survival, mortality and growth rate}

Table 1 shows number of dead individuals at each site for each measuring period. The highest mortality was observed during the first two measuring periods (Jan 15 - May 15) on all three sites.

The mean mussel length increase during the study period is given in Table 2. At all sites, all surviving individuals reached the prescribed market size $(5 \mathrm{~cm}$ in length, as defined in the OFFICIAL GAZETTE OF MONTENEGRO (8/2011; 56/2009, 47/2015)) after 13 months. At the start of the experiment, the mussels were estimated to be around 8-10 months old. At the SVN site, all surviving individuals reached market size after only 8 months, which could indicate production cycle of around 16-18 months in monoculture conditions. After the same period at site NUD $81 \%$ of survived individuals reached market size, and on site NBL $76 \%$ of survived individuals reached market size for the same period.

Growth rate analysis (length, width, height) showed a statistically significant difference in both sampling period and sampling location (Table 3 - 5; Fig. 3). The growth in length was slowest during summer period (July-September), and the most rapid in spring (Mart-May) at all sites. The same results were obtained for growth in width and height. During all periods, mussels from the SVN and NUD sites showed similar growth in length, width and height, which was significantly higher compared to the NBL site.

Table 6 shows that the estimated growth rate parameters were highest for mussels from the SVN site $\left(L_{\infty}=69.18 \mathrm{~mm}, k=1.95 \mathrm{year}^{-1}\right)$, and lowest for the NBL site $\left(L_{\infty}=62.52 \mathrm{~mm}\right.$, $k=1.709$ year $\left.^{-1}\right)$. On the NUD site estimated asymptotic length was $L_{\infty}=65.27 \mathrm{~mm}$, with $k=$ 2.079 year $^{-1}$.

\section{Condition index}

The highest values (34.47) of the condition index (CI) were recorded at the NUD site in May 2015, while the lowest values (19.28) were on the NBL site in September 2015. On all three sites, the lowest values of CI were in September 
Table 1. Number of dead individuals at each site for each measuring period

\begin{tabular}{|c|c|c|c|}
\hline Position & NBL & NUD & SVN \\
\hline Jan'15-Mar'15 $^{\prime}$ & 4 & 15 & 19 \\
\hline Mar`15-May`15 & 25 & 13 & 4 \\
\hline May'15-Jul'15 & 4 & 4 & 5 \\
\hline Jul'15-Sep'15 & 9 & 3 & 7 \\
\hline Sep'15-Nov'15 & 2 & 2 & 2 \\
\hline Nov'15-Jan`16 & 0 & 1 & 2 \\
\hline
\end{tabular}

Table 2. The mean mussel length on the beginning and after 13 months

\begin{tabular}{|l|l|l|l|}
\hline Position & NBL & NUD & SVN \\
\hline Jan'15 & $4.38 \pm 0.39 \mathrm{~cm}$ & $4.20 \pm 0.45 \mathrm{~cm}$ & $4.23 \pm 0.35 \mathrm{~cm}$ \\
\hline Jan'16 & $5.97 \pm 0.47 \mathrm{~cm}$ & $6.37 \pm 0.56 \mathrm{~cm}$ & $6.57 \pm 0.54 \mathrm{~cm}$ \\
\hline
\end{tabular}

Table 3. Analysis of growth increments for length using repeated-measures ANOVA with Tukey post hoc comparison

\begin{tabular}{lllll}
\hline Factor & d.f. & $F$ & $P$ & Post hoc comparison \\
\hline Period & 5 & 179.63 & $<0.001$ & $4<3<6<5=1<2$ \\
Site & 2 & 36.32 & $<0.001$ & NBL $<$ NUD = SVN \\
Interaction & 10 & 5.34 & $<0.001$ & \\
Error & 1248 & & \\
1 = Jan-Mar, 2 = Mar-May, 3 = May-Jul, 4 = Jul-Sep, 5 = Sep-Nov, 6 = Nov-Jan '16
\end{tabular}

Table 4. Analysis of growth increments for width using repeated-measures ANOVA with Tukey post hoc comparison

\begin{tabular}{lllll}
\hline Factor & d.f. & $F$ & $P$ & Post hoc comparison \\
\hline Period & 5 & 138.87 & $<0.001$ & $4<3=6=5<1<2$ \\
Site & 2 & 36.55 & $<0.001$ & NBL $<$ NUD = SVN \\
Interaction & 10 & 10.16 & $<0.001$ & \\
Error & 1248 & & & \\
\hline 1 = Jan-Mar, 2 = Mar-May, 3 = May-Jul, 4 = Jul-Sep, 5 = Sep-Nov, 6 = Nov-Jan '16
\end{tabular}

Table 5. Analysis of growth increment for height using repeated-measures ANOVA with Tukey post hoc comparison

\begin{tabular}{lllll}
\hline Factor & d.f. & $F$ & $P$ & Post hoc comparison \\
\hline Period & 5 & 91.91 & $<0.001$ & $4<3<6<5=1<2$ \\
Site & 2 & 32.18 & $<0.001$ & NBL $<$ NUD $=$ SVN \\
Interaction & 10 & 8.27 & $<0.001$ & \\
Error & 1248 & & & \\
\hline
\end{tabular}

1 = Jan-Mar, 2 = Mar-May, 3 = May-Jul, 4 = Jul-Sep, 5 = Sep-Nov, 6 = Nov-Jan '16 
Table 6. Growth parameters for mussels per sampling site

\begin{tabular}{cccc}
\hline & SVN & NUD & NBL \\
\hline$L_{\infty}(\mathrm{mm})$ & 69.18 & 65.27 & 62.52 \\
$k\left(\right.$ year $\left.^{-1}\right)$ & 1.95 & 2.079 & 1.709 \\
\hline
\end{tabular}

Table 7. Analysis of condition index according to site and month

\begin{tabular}{|c|c|c|c|}
\hline Year & Month & ANOVA/KW & Post hoc comparison \\
\hline & January & $\mathrm{F}=1.744^{\mathrm{NS}}$ & - \\
\hline & February & $\mathrm{H}=4.267^{\mathrm{NS}}$ & - \\
\hline & March & $\mathrm{F}=13.99 * * *$ & $\mathrm{NUD}=\mathrm{NBL}, \mathrm{SVN}>\mathrm{NBL}, \mathrm{SVN}>\mathrm{NUD}$ \\
\hline & April & $\mathrm{F}=17.22 * * *$ & $\mathrm{NUD}>\mathrm{NBL}, \mathrm{SVN}=\mathrm{NBL}, \mathrm{NUD}>\mathrm{SVN}$ \\
\hline & May & $\mathrm{F}=21.39 * * *$ & $\mathrm{NUD}>\mathrm{NBL}, \mathrm{SVN}=\mathrm{NBL}, \mathrm{NUD}>\mathrm{SVN}$ \\
\hline & June & $\mathrm{F}=5.439^{* *}$ & $\mathrm{NUD}=\mathrm{NBL}, \mathrm{SVN}=\mathrm{NBL}, \mathrm{SVN}<\mathrm{NUD}$ \\
\hline \multirow[t]{6}{*}{2015} & July & $\mathrm{F}=11.99 * * *$ & $\mathrm{NUD}>\mathrm{NBL}, \mathrm{SVN}=\mathrm{NBL}, \mathrm{NUD}>\mathrm{SVN}$ \\
\hline & August & $\mathrm{F}=4.224^{*}$ & $\mathrm{NUD}=\mathrm{NBL}, \mathrm{SVN}=\mathrm{NBL}, \mathrm{NUD}>\mathrm{SVN}$ \\
\hline & September & $\mathrm{H}=2.3446^{\mathrm{NS}}$ & - \\
\hline & October & $\mathrm{F}=13.8 * * *$ & $\mathrm{NUD}=\mathrm{NBL}, \mathrm{NBL}>\mathrm{SVN}, \mathrm{NUD}>\mathrm{SVN}$ \\
\hline & November & $\mathrm{F}=20.74 * * *$ & $\mathrm{NUD}=\mathrm{NBL}, \mathrm{NBL}>\mathrm{SVN}, \mathrm{NUD}>\mathrm{SVN}$ \\
\hline & December & $\mathrm{F}=31.65^{* * *}$ & $\mathrm{NUD}=\mathrm{NBL}, \mathrm{NBL}>\mathrm{SVN}, \mathrm{NUD}>\mathrm{SVN}$ \\
\hline 2016 & January & $\mathrm{F}=5.235^{* *}$ & $\mathrm{NUD}=\mathrm{NBL}, \mathrm{NBL}=\mathrm{SVN}, \mathrm{NUD}>\mathrm{SVN}$ \\
\hline
\end{tabular}



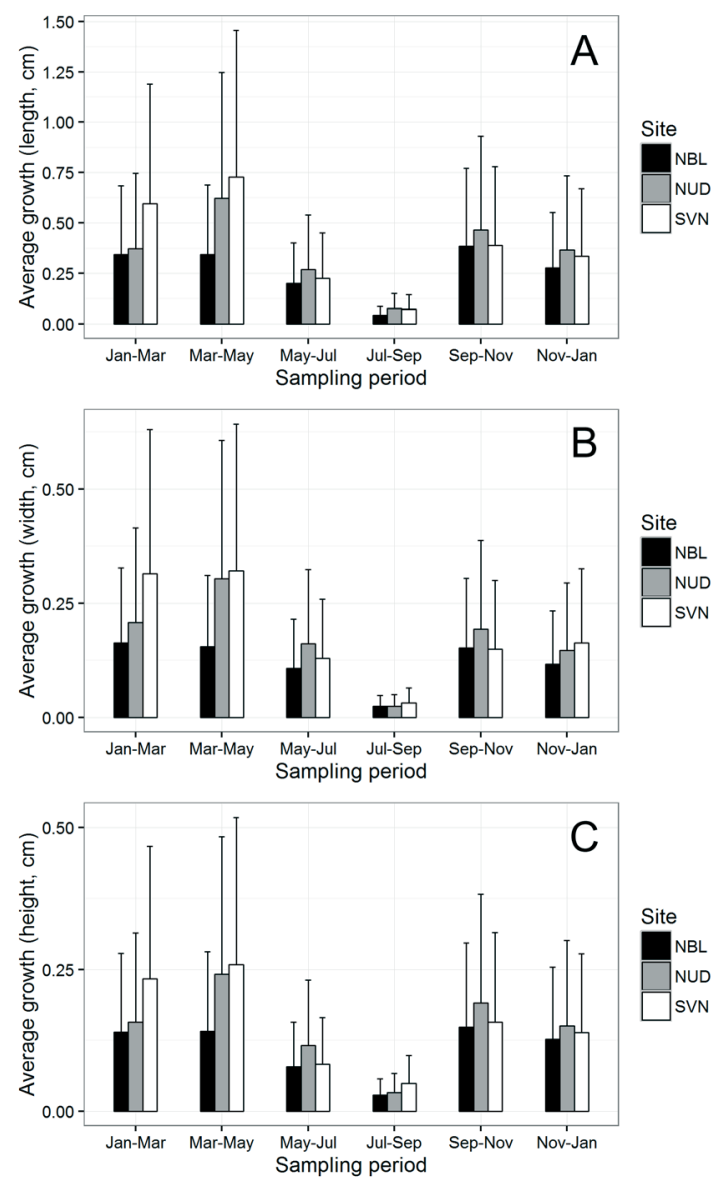

Fig. 3. Average growth increments and standard deviations for length (A), width (B), and height $(C)$ according to sampling period and location

2015 (19.28 NBL; 21.18 NUD; 19.35 SVN). During the entire monitoring period the mean values of CI were higher on the NUD site compared to the other two sites (Fig. 4), except for February and March 2015. The analysis of condition index according to site and month is given in Table 7 and shows that there was no statistically significant difference in CIs at different sites during January, February and September 2015. From April until August 2015, as well as in January 2016, the CIs at the NBL and SVN sites were similar, while in the period from October to December the individuals from the NBL site had CI values which were statistically significantly higher than the CI values of individuals from the SVN site.

\section{DISCUSSION}

The results of this study revealed statistically significant difference between sampling period and sampling location in both growth and condition index of mussels.

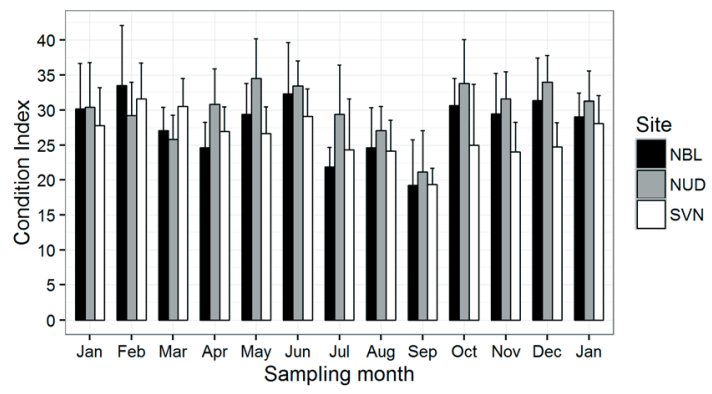

Fig. 4. Average monthly condition index and standard deviations according to month and sampling site

The obtained results indicate that growth in length, width and height at all three sampling sites was most intense in spring, and least intense in summer. These results agree with PEHARDA et al. (2007), who found the highest growth rates of mussels in period from March to May, which could indicate that the highest growth during the spring period can be the result of increased food aviability. On the other hand, results of this study partly agree with results reported by IRISARRI et al. (2014a), who found maximum growth in mussels during both spring and summer period. According to VAN ERKOM SCHURINK \& GRIFFITHS (1992) as well as ŽUPAN \& ŠARIĆ (2014), highest avaliability of food is at temperatures between $10^{\circ} \mathrm{C}$ and $20^{\circ} \mathrm{C}$, when the recorded mussel growth is most intense, while the growth slows at temperatures above $20^{\circ} \mathrm{C}$. Temperatures in the $10-20^{\circ} \mathrm{C}$ range are typical for the Adriatic in spring, with temperatures above $20^{\circ} \mathrm{C}$ typical for summer (AZCÁRATE et al., 2005), which can help explain the results obtained.

Salinity has an indirect influence on growth, with lower salinity having a positive influence, but through the fact that areas with higher influx of freshwater (and thus lower salinity) have increased amount of nutrients (ŽUPAN \& ŠARIĆ, 2014). Salinity values at the COGImar location were significantly lower during winter 
and spring seasons, compared to Sveta Neđelja (Fig. 3). The NUD site, which is about $100 \mathrm{~m}$ removed from fish cages, is under a significant influence of underwater freshwater sources, as well as the freshwater influx form the land (BELLAFIORE et al, 2011), and the higher growth rates (in length, weight and height) at this site could be attributed, at least partially, to the increased amount of freshwater.

High growth rates in length, weight and height, which were recorded at the SVN site, similar to NUD, can be connected to the strong water currents in the Verige strait $(>20 \mathrm{~cm} / \mathrm{s})$ (BELLAFIORE et al, 2011). The Sveta Neđelja mussel farm is located just off the mouth of the strait. KARAYÜCEL \& KARAYÜCEL (2000) report higher growth rate of Mytilus edulis individuals exposed to water current influence, as stronger currents carry more nutrients. BAJNOCI (2014) found that mussels which were placed on the farthest point from fish cages had the highest growth rates in length, weight and height compared to those which were placed close to fish cages, but the differences were not statistically significant. NAVARRETE-MIER et al. (2010) also did not report significant differences in shell length growth of mussels on six different distances from fish cages. Results from IRISARRI et al. (2014a) showed similar shell length between mussels close to the fish farm and mussels distant from the fish farm.

Lower growth rates at the NBL site compared to SVN and NUD site could be affected by the large amount of fouling organisms detected during the entire year on this site. STJEPČEVIĆ (1974) reports that a large amount of fouling organisms "suffocates" the mussels, which stalls their growth, and can also cause increased mortality. Dominant fouling organism on NBL site was the White sea squirt (Phallusia mammilata, Cuvier 1815). Other fouling organism which were noted are: Botryllus spp., Balanus spp., European fan worm (Sabella spallanzani, Gmelin 1791), Keel worm (Pomatoceros triqueter, Linnaeus 1758) and Bryozoa (Schizobrachiella sanguine, Norman 1868). All of those organisms were also recorded on the other two localities, but in different abundances. On the SVN site Keel worm was more abundant that any other organisms, as well as the European fan worm, while on NBL and NUD site White sea squirt was the dominant organism. Also, on the NBL and NUD sites the green algae Chaetomorpha spp. and Cladophora spp. were abundant, especially during spring months. These differences in fouling can be explained by the differences in sea currents at different localities.

The highest mortality in our study was recorded during the the first two measurement periods on all three sites, which can be explained by stress and adaptation of individuals to the new conditions (ŽUPAN, 2012). On the other hand, higher mortality at the NBL site during the entire monitoring period could be explained by an increased presence of fouling organisms due to the proximity of fish cages.

It is known that condition index is an important parameter indicating the quality of shellfish (ŽUPAN \& ŠARIĆ, 2014). The results of this study indicate that location did consistently influence the CI of mussels, with individuals $100 \mathrm{~m}$ removed from fish cages (NUD) showing higher CI values for the major part of the study compared to individuals at the other two sites (NBL, SVN), which were quite similar among themselves, exept for the colder period (October-December) when sites NBL and NUD were similar and had higher CI values. These results can indicate the fact that in colder months, when primay production is lower and there is little food available in water, mussels feed on the nutrients originating from fish farms . The benefits on mussels feeding on fish farm effluents were noted by MACDONALD et al. (2011).

This study's results regarding the CI are in accordance with those reported by SARÁ et al. (2009), LANDER et al. (2012) and ŽUPAN et al. (2014), who found a positive correlation between CI values in bivalves and their proximity to fish farms. IRISARRI et al. (2014b) found significantly higher CI in IMTA mussels than in monoculture individuals. On the other hand, the results of this study are not consistent with the results of TAYLOR et al. (1992) and CHESHUK et al. (2003), 
who showed that there is no influence of salmon farming on CI of M. edulis and M. planulatus. IRISARRI et al. (2014a) has not found differences in CI values among mussels close to the fish farm and those distant from the fish farm. Also, NAVARRETE-MIER et al. (2010) did not report significant differences in dry weight of mussels farmed on six different distances from fish cages.

The results of this study also showed the lowest CI values during September 2015 at all three sites. This can be explained by the common spawning period of the mussel, which reaches its peak during spring and autumn (DARDIGNAC-CORBEL, 1990). However, even if the bibliographical data refer to spring spawning closely following the drop in CI values (MASON, 1976; OKUMUŞ \& STIRLING, 1998; PEHARDA et al., 2007), this was not recorded in this study. Rather, the CI values were relatively high at all three sampling sites. According to HRS-BRENKO (1980), water temperatures above $16^{\circ} \mathrm{C}$ have a significant effect on the reduction of sexual activity of mussels. It is important to mention that method for CI calculation in this study was based on "wet" method (ALMEIDA et al. 1999), while calculation of CI in most other studies was based on dried or cooked meat (FREEMAN, 1974; DAVENPORT \& CHEN, 1987).

\section{CONCLUSIONS}

This study analysed the growth rate and condition index of $M$. galloprovincialis in integrated system and monoculture. The growth rate and condition index were monitored during a 13-month study at three different sites: 1) close to the fish cages (NBL), 2) $100 \mathrm{~m}$ far from fish cages (NUD), and 3) at a monoculture mussel farm (SVN). Significant differences in growth rate and condition index according to sampling period and location were found. The results showed a similar production cycle in monoculture and integrated multi-trophic systems. The highest mortality rate was recorded at the NBL site. The results of the study refer to the minimum market size of musels in Montenegro (5 cm shell length) (OFFICIALL GAZETTE OF MONTENEGRO, 8/2011; 56/2009, 47/2015). As such, the results of the study might not be directly applicable to areas with different minimum market sizes e.g. in Croatia, where mussel minimum market size is $6 \mathrm{~cm}$ (OFFICIAL GAZETTE OF THE REPUBLIC OF CROATIA, 63/10, 68/10, 145/10, $18 / 12,29 / 12)$, although they should be considered indicative. CI results indicate the possibility that mussels feed on the nutrients from fish farm during periods when little food would naturally be available in water.

It is known that, besides temperature and salinity, the other important factors influencing growth in mussels are the availability of food, water current direction and population density (GOSLING, 1992), and that food availability and changes in the reproduction phases are the most important factors in CI variations (GOSLING, 1992), the obtained results suggest that a much more detailed study, which would include abiotic and biotic parameters on all sampling locations, should be performed in order to get more relevant results.

\section{ACKNOWLEDGMENTS}

This study was been supported by the Ministry of Science of Montenegro and the HERIC project through the BIO-ICT Centre of Excellence (Contract No. 01-1001), and also by the Ministry of rural development and agriculture - Monitoring of water quality at mussel and fish farms for the period 2014-2015, financed through the Agro-budget. 


\section{REFERENCES}

AL-HAFEDH, Y. S., A. ALAM \& A. H. BUSCHMANN. 2014. Bioremediation potential, growth and biomass yield of the green seaweed, Ulva lactuca in an integrated marine aquaculture system at the Red Sea coast of Saudi Arabia at different stocking densities and effluent flow rates. Reviews in Aquaculture, 6: 1-11.

ALMEIDA, M. J., J. MACHADO, J. COIMBRA. 1999. Growth and bio-chemical composition of Crassostrea gigas (Thunberg) and Ostrea edulis (Linne) in two estuaries from the North of Portugal. J. Shellfish Res., 18: 139-146.

ABREU, M.H., D.A. VARELA, L. HENRÍQUEZ, A. VILLARROEL, C. YARISH, I. SOUSA-PINTO \& A.H. BUSCHMANN. 2009: Traditional vs. integrated multi-trophic aquaculture of Gracilaria chilensis C. J. Bird, J. McLachlan \& E. C. Oliveira: Productivity and physiological performance. Aquaculture, 293: 211-220.

AZCÁRATE, A.A., A. BARTH, M. RIXEN \& J.M. BECKERS. 2005. Reconstruction of incomplete oceanographic data sets using empirical orthogonal functions: application to the Adriatic Sea surface temperature. Ocean Model., 9(4): 325346.

BAJNOCI, A. 2014. Učinci organskog unosa kaveznim uzgojem ribe na kondiciju dagnji (Mytilus galloprovincialis) u Bistrini. Diplomski rad. Sveučilište u Dubrovniku, 36 pp.

BELLAFIORE, D., A. GUARNIERI, F. GRILLI, P. PENNA, G. BORTOLUZZI, F. GIGLIO \& N. PINARDI. 2011. Study of the hydrodynamical processes in the Boka Kotorska Bay with a finite element model. Dynam. Atmos. Oceans, 52: 298-321.

CHÁVEZ-CROOKER, P., J. OBREQUE-CONTRERAS. 2010. Bioremediation of aquaculture wastes. Curr. Opin. Biotechol., 21: 313317.

CHESHUK, B.W., G.J. PURSER \& R. QUINTANA. 2003. Integrated open-water mussel (Mytilus planulatus) and Atlantic salmon (Salmo salar) culture in Tasmania. Australia. Aquaculture, 218: 357-378.

CHOPIN, T. \& S.M.C. ROBINSON. 2004. Defining the Appropriate Regulatory and Policy Framework for the Development of Integrated Multi-Trophic Aquaculture Practices: Introduction to the Work shop and Positioning of the Issues. B. Aquac. Ass. Can., 104(3): 4-10.

DARDIGNAC-CORBEL, M.J. 1990. Traditional mussel culture. In: D.G. Barnabe (Editor). Aquaculture Vol. I. Ellis Horwood Chichester, 284-341 pp.

DAVENPORT, J. \& X. CHEN. 1987. A comparison of methods for the assessment of condition in the mussel (Mytilus edulis L.). Journal of Molluscan Studies, 53: 293-297.

DAVENPORT, J., R.J.J.W. SMITH, M. PACKER. (2000): Mussels Mytilus edulis: significant consumers and destroyers of mesozooplankton. Mar. Ecol. Prog. Ser., 198: 131-137.

FAO. 2004. The state of world fisheries and aquaculture. Food and Agriculture Organisation of the United Nations, Rome, Italy, FAO, 154pp.

FAO. 2009. Integrated mariculture - a global review. Food and Agriculture Organisation of the United Nations, Rome, Italy, FAO, 194 pp.

FAO. 2010. The state of world fisheries and aquaculture. Food and Agriculture Organisation of the United Nations, Rome, Italy, FAO, 218pp.

FREEMAN, K. R. 1974. Growth, mortality and seasonal cycle of Mytilus edulis in two Nova Scotian embayments. Bedford Institute of Oceanography, Dartmouth, Canada.

GAYANILO, P.C., P. SPARRE \& D. PAULY. 2005. FAOICLARM Stock Assessment Tools II User's Guide. FAO. Rome, Italy. 168 pp. GISD. 2016. Global Invasive Species Database, Mytilus galloprovincialis. Available from http://www.iucngisd.org/gisd/species. $\mathrm{php}$ ?sc $=102 \#$. 
GOSLING, E. 1992. The mussel Mytilus: Ecology, Physiology, Genetics and Culture. Developments in aquaculture and fisheries science. Elsevier, Amsterdam, 25: 589 pp.

HANDÅ, A., H. MIN, X. WANG, O.J. BROCH, K.I. REITAN, H. REINERSTEN \& Y. OLSEN. 2012: Incorporation of fish feed and growth of blue mussels (Mytilus edulis) in close proximity to salmon (Salmo salar) aquaculture: Implications for integrated multi-trophic aquaculture in Norwegian coastal waters. Aquaculture, 356-357: 328-341.

HOLDT, S. L. \& M. D. EDWARDS. 2014. Costeffective IMTA: a comparison of the production efficiencies of mussels and seaweed. J. App. Phycol.

HRS-BRENKO, M. 1980. The settlement of mussels and oysters in the northern Adriatic Sea. Nova Thalassia 4(suppl.): 67- 85.

HUGHES, A.D. \& M.S. KELLY. 2011. Integrated multi-trophic aquaculture. Scottish Association of Marine Science, 15 pp. Available online at: http://www.sarf.org. uk/cmsassets/documents/28926-823833. current-state-of-integrated-aquaculture.

IRISARRI, J., A.M. CUBILLO, M.J. FERNÁNDEZREIRIZ, U. LABARTA. 2014A. Growth variations within a farm of mussel (Mytilus galloprovincialis) held near fish cages: importance for the implementation of integrated aquaculture. Aqua. Res., $1-15$.

ISARRI, J. J., M. J. F. REIRIZ, U. LABARTA, P. J. CRANFORD \& S. M. C. ROBINSON. 2014B. Availability and utilization of waste fish feed by mussels Mytilus edulis in a commercial integrated multi-trophic aquaculture (IMTA) system: A multiindicator assessment approach. Ecological Indicators, 48: 673-686.

KARAYÜCEL, S. \& I. KARAYÜCEL. 2000. The effect of environmental factors, depth and position on the growth and mortality of raft-cultured blue mussels (Mytilus edulis L.). Aquac. Res, 31: 893-899.

LANDER, T.R., S.M.C. ROBINSON, B.A. MACDONALD \& J.D. MARTIN. 2012. Enhanced growth rates and condition index of blue mussels
(Mytilus edulis) held at integrated multitrophic aquaculture sites in the Bay of Fundy. J. Shellfish Res., 31(4): $997-$ 1007.

MACDONALD, B. A., S. M. C. ROBINSON \& K. A. BARRINGTON. 2011. Feeding activity of mussels (Mytilus edulis) held in the field at an integrated multi-trophic aquaculture (IMTA) site (Salmo salar) and exposed to fish food in the laboratory. Aquaculture, 314: 244-251.

MACDONALD, C. L. E., S. M. STEAD, \& M. J. SLATER. 2013. Consumption and remediation of European seabass (Dicentrarchus labrax) waste by the sea cucumber Holothuria forskali. Aquac. Int., 21:1279-1290.

MASON, J. 1976. Cultivation. In: B.L. Bayne (Editor) Marine mussels: their ecology and physiology. Cambridge University Press, Cambridge, str. 385-410.

MAZZOLA, A. \& G. SARÀ. 2001. The effect of fish farming organic waste on food availability for bivalve molluscs (Geata Gulf, Central Tyrrhenian, MED): stable carbon isotopic analysis. Aquaculture, 192: 367-379.

MONSTAT. 2014. Statistical Office of Montenegro. Proizvodnja ribe i školjaka - akvakultura i marikultura (Production of fish and shellfish - aquaculture and mariculture). Available online at: http://www.monstat. $\mathrm{org} / \mathrm{cg} /$ page. php? $\mathrm{id}=265$ \& pageid $=162$.

NAVARRETE-MIER, F., C. SANZ-LÁZARO, A. MARÍN. 2010. Does bivalve mollusc polyculture reduce marine fin fish farming environmental impact? Aquaculture, 306: 101-107.

OFFICIAL GAZETTE OF MONTENEGRO. 2009. Zakon o morskom ribarstvu i marikulturi (Law on marine fisheries and mariculture). Službeni list Crne Gore 56/2009, Podgorica, Montenegro.

OFFICIAL GAZETTE OF MONTENEGRO. 2011. Naredba o zabrani lova i stavljanja u promet riblje mlađi, nedoraslih riba $i$ drugih morskih organizama (Order on prohibition of catch and trade in fish juveniles, undersized fish and other marine organisms). Službeni list Crne Gore 8/2011, Podgorica, Montenegro. 
OFFICIAL GAZETTE OF MONTENEGRO. 2015. Zakon o izmjenama i dopunama Zakona o morskom ribarstvu i marikulturi (Law on changes and additions to the Law on marine fisheries and mariculture). Službeni list Crne Gore 47/2015, Podgorica, Montenegro.

OFFICIAL GAZETTE OF THE REPUBLIC OF CROATIA. 2010. Naredba o zaštiti riba $i$ drugih morskih organizama (Regulation on the protection of fish and other marine organisms). Narodne novine 63/10, Zagreb, Croatia.

OFFICIAL GAZETTE OF THE REPUBLIC OF CROATIA. 2010. Ispravak Naredbe o zaštiti riba $\mathrm{i}$ drugih morskih organizama (Correction of the Regulation on the protection of fish and other marine organisms). Narodne novine 68/10, Zagreb, Croatia.

OFFICIAL GAZETTE OF THE REPUBLIC OF CROATIA. 2010. Naredba o dopuni Naredbe o zaštiti riba i drugih morskih organizama (Regulation on the addition to the Regulation on the protection of fish and other marine organisms). Narodne novine 145/10, Zagreb, Croatia.

OFFICIAL GAZETTE OF THE REPUBLIC OF CROATIA. 2012. Naredba o dopuni Naredbe o zaštiti riba i drugih morskih organizama (Regulation on the addition to the Regulation on the protection of fish and other marine organisms). Narodne novine 18/12, Zagreb, Croatia.

OFFICIAL GAZETTE OF THE REPUBLIC OF CROATIA. 2012. Naredba o izmjeni Naredbe o zaštiti riba i drugih morskih organizama (Regulation on the change to the Regulation on the protection of fish and other marine organisms). Narodne novine 29/12, Zagreb, Croatia.

OKUMUŞ, I. \& H.P. STIRLING. 1998. Seasonal variation in the meat weight, condition index and biochemical composition of mussels (Mytilus edulis L.) in suspended culture in two Scottish sea lochs. Aquaculture, 159: 249-261.

PEHARDA, M., I.ŽUPAN, L. BAVČEVIĆ, A. FRANKIĆ \& T. KLANJŠČEK. 2007. Growth and condition index of mussel Mytilus galloprovincialis in experimental integrated aquaculture. Aquac. Res., 38: 1714-1720.

PRATO, E., A. DANIELI, M. MAFFIA \& F. BIANDOLINO. 2010. Lipid and fatty acid compositions of Mytilus galloprovincialis cultured in the Mar Grande of Taranto (Southern Italy): feeding strategies and trophic relationships. Zool. Stud., 49(2): 211-219.

RATCLIFF, J. J., A. H. L. WAN, M. D. EDWARDS, SOLER-VILA, A., M. P. JONSON, M. H. ABREU \& L.MORRISON. 2015. Metal content of kelp (Laminaria digitata) co-cultivated with Atlantic salmon in an Integrated Multi-Trophic Aquaculture system. Aquaculture, 450: 234-243.

REID, G.K., M. LIUTKUS, A. BENNETT, S.M.C. ROBINSON, B. MACDONALD \& F. PAGE. 2010. Absorption efficiency of blue mussels (Mytilus edulis and M. trossulus) feeding on Atlantic salmon (Salmo salar) feed and fecal particulates: Implications for integrated multi-trophic aquaculture. Aquaculture, 299: 165-169.

REDMOND, K.J., T. MAGNESEN, P.K. HANSEN, Ø. STRAND \& S. MEIER. 2010. Stable isotopes and fatty acids as tracers of the assimilation of salmon fish feed in blue mussels (Mytilus edulis). Aquaculture, 298: 202-210.

SARÀ, G., A. ZENONE \& A. TOMASELO. 2009. Growth of Mytilus galloprovincialis (mollusca, bivalvia) close to fish farms: a case of integrated multi-trophic aquaculture within the Tyrrhenian Sea. Hydrobiologia, 636(1): 129-136.

SARÀ, G., G.K. REID, A. RINALDI, V. PALMERI, M. TROELL \& S.A.L.M. KOOIJMAN. 2011. Growth and reproductive simulation of candidate shellfish species at fish cages in the Southern Mediterranean: Dynamic Energy Budget (DEB) modelling for integrated multi-trophic aquaculture. Aquaculture, 324-325: 259-266.

STJEPČEVIĆ, J. 1968. Biologija i tehnološki process uzgoja jadranske kamenice (Ostrea edulis L.) (Biology and technological process of Adriatic oyster (Ostrea edulis L.) farming). Agriculture and Forestry, 13(4): 
33-48.

STJEPČEVIĆ, J. 1974. Ekologija dagnje Mytilus galloprovincialis L. i kamnenice Ostrea edulis L. u gajilištima Bokokotorskog zaliva (Ecology of the mussel Mytilus galloprovincialis L. and oyster Ostrea edulis L. on farms in the Boka Kotoska bay). Stud. Mar., 7: 3-164.

SUDAREVIĆ, J. 1992. Analiza ekonomskih efekata uzgoja šoljaka u Malostonskom zaljevu (Analysis of economical effects of shellfish farming in the Malostonski Bay). Master thesis, University of Zagreb, $158 \mathrm{pp}$.

TAYLOR, E. B., G. JAMIESON \& T. CAREFOOT. 1992. Mussel culture in British Columbia: the influence of salmon farms on growth of Mytilus edulis. Aquaculture, 108: 51-56.

TROELL, M, A. JOYCE, T. CHOPIN, A. NEORI, A.H. BUSCHMANN \& J.G. FANG. 2009. Ecological engineering in aquaculture - Potential for integrated multi-trophic aquaculture (IMTA) in marine offshore systems. Aquaculture, 297: 1-9.

VAN ERKOM SCHURINK, C. \& C.L. GRIFFITHS. 1992. Physiological energetics of four South African mussel species in relation to size, ration and temperature. Comp. Biochem. Physiol., 101: 779-789.

ŽUPAN, I. 2012. Integralni uzgoj dagnje (Mytilus galloprovincialis Lamarck, 1819) i kunjke (Arca noae linnaeus, 1758) na uzgajalištima riba (Integral farming of Mussel (Mytilus galloprovincialis Lamarck, 1819) and Noah's Ark (Arca noae Linnaeus, 1758) on fish farms). Doctoral thesis. University of Split and University of Dubrovnik, $120 \mathrm{pp}$.

ŽUPAN, I., M. PEHARDA, L. BAVČEVIĆ, T. ŠARIĆ, \& D. KANSKI. 2012. Potential for development of integrated multi-trophic aquaculture (IMTA) in the Adriatic sea. Ribarstvo, 70:125-137.

ŽUPAN, I., J. ROGOŠIĆ, T. ŠARIĆ, \& D. KANSKI. 2013. Transfer of Arca noae Linnaeus, 1758 from natural to different experimental farming conditions. Ribarstvo, 71(4): 187-191.

ŽUPAN, I. \& T. ŠARIĆ. 2014. Prirast i indeks kondicije - dva važna čimbenika u uzgoju dagnji (Growth and condition index - two important factors in mussel farming). MESO, 16: 255-259.

ŽUPAN, I., M. PEHARDA, T. DOLENEC, M. DOLENEC, P.Ž. ROŽIČ, S. LOJEN, D.E. BALIĆ \& J. ARAPOV. 2014. Aquaculture Assessment of Noah's Ark (Arca noae Linnaeus, 1758) in The Central Adriatic Sea (Croatia). J. Shellfish Res., 33(2): 433-441.

Received: 30 January 2017

Accepted: 27 July 2017 


\title{
Usporedba između IMTA i uzgoja dagnje u monokulturi (Mytilus galloprovincialis L.) u Bokokotorskom zaljevu
}

\author{
Slađana GVOZDENOVIĆ, Milica MANDIĆ, Vladimir PEŠIĆ, Marko NIKOLIĆ, \\ Ana PEŠIĆ i Zdravko IKICA* \\ *Kontakte-adresa: zdikica@ac.me
}

\begin{abstract}
SAŽETAK
Cilj ovog istraživanja bio je pokazati postojanja mogućih razlika u rastu i kondicijskom indeksu dagnji (Mytilus galloprovincialis) u integralnom multi-trofičkom uzgoju i uzgoju u monokulturi. Rast i kondicijski indeks praćeni su tijekom razdoblja od 13 mjeseci na tri postaje: 1) u blizini uzgajališta ribe (NBL), 2) $100 \mathrm{~m}$ od uzgajališta ribe (NUD), 3) u monokulturi (SVN) na uzgajalištu koje je oko $8 \mathrm{~km}$ udaljeno od kaveza sa ribom. Najintenzivniji rast zabilježen je tijekom proljetnog razdoblja, a najmanje intenzivan tijekom ljetnog. Nakon 13 mjeseci, praćene jedinke su na sve tri pozicije dostigle komercijalnu dužinu. Stopa rasta je bila slična na sve tri pozicije, dok je kondicijski indeks pokazao prostorne i vremenske razlike. Vrijednosti kondicionog indeksa na postaji NUD bile su više od vrijendosti na postajama SVN i NBL, koje su međusobno bile prilično slične, osim u razdoblju od listopada do prosinca kada su vrijednosti kondicijskog indeksa bile slične na postajama NBL i NUD, a veće u usporedbi sa vrijednostima na postaji SVN poziciji. Vrijednosti kondicionog indeksa na postajama NBL i NUD tijekom hladnog perioda godine ukazuju na to da se dagnje vjerovatno hrane nutrijentima porijeklom sa uzgajališta riba. Visoki mortalitet zabilježen je na postaji NBL, najvjerojatnije zbog obraštajnih organizama.
\end{abstract}

Ključne riječi: Mytilus galloprovincialis, integralna multi-trofička akvakultura, monokultura, Bokokotorski zaljev 